\title{
Compostrade: E-commerce Model for Agricultural Waste
}

\author{
Panduaji Panditatwa ${ }^{1}$, Erdi Pratama ${ }^{1}$, and Ario Ananda Alifianto ${ }^{2}$ \\ ${ }^{1}$ Student in Department of Agribusiness, Faculty of Economics and Management, Bogor Agricultural University \\ ${ }^{2}$ Student in Department of Management, Faculty of Economics and Management, Bogor Agricultural University
}

\begin{abstract}
Agricultural activities produce wastes that can be utilized. Information on supply and demand of agricultural wastes is less available. As a result, not all agricultural wastes are utilized properly. Compostrade is an e-commerce model that connects agricultural waste producers and processors. They both enroll and agree on a contract to be able to do transaction with Compostrade. This model focuses on economical agricultural wastes segment. The target of this model is a business unit that produces agricultural waste and another business unit that processes agricultural waste. Compostrade is positioned as the third party and services provider in the transaction of agricultural wastes. Flow of services flows from compostrade to sellers and buyers. Flow of goods flows from sellers to buyers. Cash flows from buyers to sellers. Compostrade provides transportations and bailouts. Compostrade also promotes secondary products produced by waste processors.
\end{abstract}

Keywords: flow of goods, flow of service and third party.

\section{Introduction}

Refer to OECD ${ }^{1}$, Agricultural waste is waste produced as a result of various agricultural operations. It includes manure and other wastes from farms, poultry houses and slaughterhouses; harvest waste; fertilizer runoff from fields; pesticides that enter into water, air or soils; and salt and silt drained from fields. Meanwhile, EAUC ${ }^{2}$ states that Agricultural waste is defined as 'waste from premises used for agriculture within the meaning of the Agriculture Act 1947, the Agriculture (Scotland) Act 1948 or the Agriculture Act (Northern Ireland) 1949'. Agriculture may therefore include some activities such as horticulture; fruit growing; seed growing; dairy farming and livestock breeding and keeping; use of land as grazing land, meadow land, market gardens and nursery grounds; use of land for woodlands where that use is ancillary to the farming of land for other agricultural purposes.

According to Davis and Goldberg (1957), post-harvest activity; such as the storage, processing and distribution of farm commodities and items made from them; also included to agricultural operation. Those postharvest activities also produce wastes such as rind, fruit stem, fruits and vegetables rot. In this model, postharvest activity wastes are included as agricultural waste.

Economically, wastes can be divided into two types, economical waste and non-economical waste. Economical waste can contain added value after processed through some processing activities. On the other hand, non-economical waste cannot contain any added value if processed further. The processing of non-economical waste is conducted to simplify the process of transporting, not for giving it added value. (Kristanto, 2008),

Nowadays, there are many agricultural wastes alternative uses. Traditionally, agricultural wastes reuse in agricultural cultivation. Agricultural wastes are processed into fertilizer or animal feed so that they can be used again. As the impact of technology development, today agricultural wastes can be processed into some variative valuable products, such as culinary products, health products and beauty products. According to Kristanto (2008), agricultural wastes are classified as economical waste.

Unfortunately, not all of agricultural wastes are processed into valuable products. This happens because of the lack of information of agricultural waste supply and demand. As the result, agricultural business unit which

\footnotetext{
${ }^{1}$ The Organisation for Economic Co-operation and Develompment

${ }^{2}$ The Environmental Association for Universities and Colleges
} 
produces wastes find it hard to search for business units which can hold their wastes. On the other side, business units which process wastes also find it hard to meet their needs.

As the solution of these problems, an e-commerce model is needed. This model is able to give added value to agricultural wastes. According to Johnson (2005), e-commerce is a business transaction activity electronically via internet as the main communication media. According to Laudon \& Laudon (2010), e-commerce business transaction can be conducted inter-company and also between companies and consumers.

\section{Explanation of The Model}

\subsection{General Overview}

Compostrade is an agricultural e-commerce model which connects agricultural waste producers and agricultural waste processors. This model uses data-basis on a web. The users of this model can be a single business unit or a group of business unit in an area.

In the interest of using this e-commerce model, agricultural waste producers and agricultural waste processors have to register to the data-basis on a web to do the transaction among others. Some data must be uploaded to the web in case to register in this model, such as kind of agricultural wastes produced or processed and waste availability schedule. The uploaded data is used to match the schedules among producers and processors.

After signed up, business units must agree with the transactional terms and conditions. That contract regulates the interactions among waste producers, waste processors and the Compostrade. As the result of it, needs of those three can be guaranteed and protected through this mechanism.

On the Business to Business (B2B) system, Compostrade has a role as the third party of agricultural waste producers and agricultural waste processors to do transaction. Compostrade will provide agricultural waste gathering, packaging and delivery service from producers to processors. As the compensation of its services, Compostrade will get profit sharing from every transaction among them.

For every gathering service done by Compostrade, Compostrade will be helped by operators in every area to gather small-scale agricultural wastes such as vegetable or fruit wastes in the traditional market and rice grain waste from conventional farmers. Those operators are residents in the area who will be trained to input waste data to Compostrade and do packaging. The packaging of those agricultural wastes can be different; it depends on kinds of wastes packaged.

While the packaging service will be done by operator, the delivery service will be done by Compostrade in cooperation with shipping company. The performance of operators will be supervised by surveyor or Compostrade itself. This should be done to do check and balance and verification of waste availability data.

Compostrade stimulate continuous processing of agricultural wastes. Those wastes will be processed to create creative and innovative products by giving them additional value, such as handcrafts, organic composts, natural dyes etc. It depends on the characteristics of waste produced. Those products will be sold directly to consumers. As the result of this activity, consumer will get low price products. This activity also can absorb many labors to reduce unemployment in society.

All of the activities done by Compostrade are oriented to The Triple Bottom Line (People, Planet and Profit) to create sustainable business unit (Elkington et al., 2005). People, Compostrade does community empowerment in waste processing to create a labour intensive business unit. Planet, Compostrade contributes to reduce and recycle agricultural wastes by giving them additional value. Profits, profits gained by Compostrade are used as business stimulus, in order that all of these activities run well.

\subsection{Marketing Mix (Segmentation, Targeting and Positioning)}

Compostrade focuses on service-based business in economical agricultural wastes segment. Wastes in this segment are relatively available in large quantities. Along with efforts to increasing agricultural productivity, 
availability of this waste is significantly increasing. On the other side, efforts to process agricultural wastes become valuable products are continuously conducted.

The main target of this model is business units which produce agricultural wastes and business units which process agricultural wastes. To Compostrade, business units which produce agricultural wastes have a role as the input providers. The input providers can be a single business unit or collaboration of some business units located in same area. On the other hand, business units which process agricultural wastes have a role as the output users in this model.

This model is positioned as the third party, and also service provider in the agricultural waste transaction. Sellers are business units which produce agricultural wastes, and buyers are business units which process agricultural wastes. Compostrade connects sellers and buyers through services provided, but Compostrade does not provide storage service, because of perishable nature of agricultural wastes. Wastes received from sellers are directly distributed to buyers under the contract.

\subsection{Service, Goods and Cash Flow}

As service provider, Compostrade distributes its service to seller and buyer. Compostrade provides convenience for seller and buyer in the transaction. Meanwhile, wastes are distributed from producers as sellers to processors as buyers. Compostrade does wastes buying transaction to producers as sellers, after that, those wastes are resold by Compostrade to processors as buyers. In this transaction, wastes are directly sold to processors by Compostrade. As the feedback in this transaction, cash flow flows from processors as buyers to producers as seller. Cash paid equals to wastes transacted by buyers and Compostrade. Besides, buyers also give cash money to Compostrade as service payment. After that, cash is paid to producers as sellers by Compostrade. Cash paid equals to wastes transacted minus service payment that has been done by Compostrade.

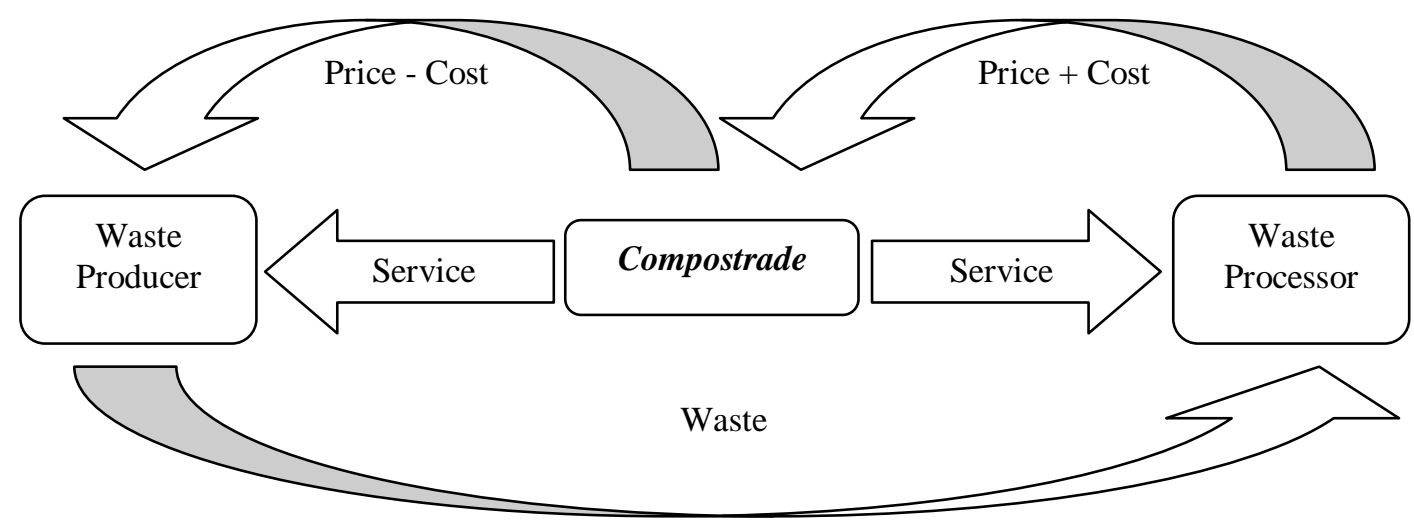

Fig 1: Service, Goods and Cash Flow.

\subsection{Services}

Compostrade has a role as the service provider among agricultural wastes producers and their processors. Compostrade picks up wastes from wastes producers, and then delivers them to waste processors. To support its service, Compostrade collaborates with operators in every area and other companies which have moving trucks to take away solid wastes and tanker to take away wastewaters and sewage pastas. Compostrade also provides bailout service. This service is especially intended for waste processors. It takes time for waste processors to gain profits from waste processed. Compostrade will buy them firstly from waste producers as sellers. Then, 
processors as buyers can buy them from Compostrade and pay them after the wastes processed and gain profits from them.

\subsection{Marketing Agent}

In this case, Compostrade needs supports of marketing agents. As we can see, not all of agricultural wastes producer aware of their wastes. They usually prefer disposing them than making them valuable if wastes processed further. Those agents provides counseling to agricultural wastes producers to cooperate with Compostrade in order to make those wastes valuable and gain profits from them. Those agents also demonstrates wastes packaging and data inputting demo to lay waste producers to familiarize them with service given by Compostrade. After waste producers start being aware of their agricultural wastes produced, automatically they will sign up to Compostrade and use service provided by Compostrade.

\subsection{Secondary Product Marketing}

Wastes produced by buyers will be processed by processors to produce products resulting from the processing of waste. Those products are called secondary products. Compostrade supervises waste processors in processing waste to produce valuable goods from them. The waste processors will gain profits from their sales and continuously produce valuable goods from agricultural wastes provided by Compostrade. As the feedback of this activity, the transaction among waste producers, waste processors and Compostrade will continuously conduct.

\section{Acknowledgements}

The authors wish to thank to our lecturer, Tintin Sarianti who has directed us in developing this model to this work. We also would like to thank to our institution, Bogor Agricultural University which have supported us in many ways. This work would never be created without some helps from our other lecturers and colleagues. We hope that this work will be advantageous for our environment, social welfare and society.

\section{References}

[1] (2015). Agricultural Waste - More Detail. The Environmental Association for Universities and Colleges. Available: http://www.eauc.org.uk/page.php?subsite=waste\&page=agricultural_waste_-_more_detail

[2] (October 2001). Glossary of Statistical Terms: Agricultural Waste. The Organisation for Economic Co-operation and Development. Available: https://stats.oecd.org/glossary/detail.asp?ID=77

[3] K. C. Laudon and J. P. Laudon, Management Information System, 11st Ed. New Jersey, U.S.: Pearson Prentice Hall, 2010.

[4] P. Kristanto, Ekologi Industri, Yogyakarta, Indonesia: Penerbit ANDI, 2008.

[5] R. Kasali, Cracking Zone, Jakarta, Indonesia: PT Gramedia Pustaka Utama, 2010. 